\title{
BUSINESS MODEL INNOVATION FOR SMALL MEDIUM ENTERPRISES
}

\author{
Wirania Swasty \\ Visual Communication Design, School of Creative Industries, Telkom University \\ Jl. Telekomunikasi no. 1 Terusan Buah Batu- Bandung, Indonesia \\ wirania@tcis.telkomuniversity.ac.id
}

\begin{abstract}
Indonesian economy through Small Medium Enterprises (SMEs) is expected to absorb labor and contribute to the growth of Gross Domestic Product. However, SMEs lack both managerial and technical skills. This research is about business model innovation for SMEs especially in fashion and garment industry.Study used qualitative approach by mentoring four selected SMEs in Babakan Penghulu Village- Cinambo SubDistrict, Eastern Bandung. The tools used to analyze them including PEST analysis, Porter's Five Forces, Resource Based View, Value Chain Analysis and Business Model Canvas. Finding suggests SMEs to have business model innovation derived from value proposition. SMEs should build their own brand awareness. Moreover, as garment and fashion industry, design can be a particularly important part of the Value Proposition. SMEs could communicate its value propositions and inform their service through its official websites and other social media. Since the intangible resources include brand and design, thus SMEs should build brand image and innovate year by year. SMEs must hire designers and launch a series of new products offers under the signature of their own brands.Ideation to strengthen strategies derives from value proposition building block as a starting point. Moreover, Business Model Canvas makes strategy more focused and measurable. Business model innovation is expected to increase overall performance of SMEs.
\end{abstract}

Keywords: SME, business model, business model innovation, creative industry, value proposition

\begin{abstract}
ABSTRAK
Perekonomian Indonesia melalui Usaha Kecil dan Menengah (UKM) diharap mampu menyerap lapangan kerja dan berkontribusi terhadap kenaikan Produk Domestik Bruto. Namun UKM kurang dalam keahlian manajerial dan teknologikal. Paper ini bertujuan untuk mengungkapkan inovasi model bisnis bagi UKM terutama industry busana dan garmen. Studi menggunakan pendekatan kualitatif dengan melakukan pendampingan pada empat UKM di Desa Babakan Penghulu- Kecamatan Cinambo, Bandung. Alat-alat yang digunakan untuk menganalisis hal tersebut termasuk analisis PEST, Porter's Five Forces, Pandangan berdasar Sumber Daya, Analisis Rantai Nilai and Kanvas Model Bisnis. Business Model Canvas. Penemuan menyarankan UKM memiliki inovasi model bisnis yang berasal dari proposisi nilai.UKM sebaiknya membangun kesadaran mereknya sendiri. Terlebih lagi, sebagai industry garmen dan busana, desain dapat menjadi bagian penting dari proposisi nilai. UKM dapat mengomunikasikan proposisi nilainya dan menginformasikan layanan mereka melalui situs resmi dan media social lainnya. Karena sumber daya tak terukur meliputi merek dan desain, maka UKM sebaiknya membangun citra merek dan berinovasi dari tahun ketahun. UKM harus mempekerjakan desainer dan meluncurkan produk baru di bawahmereksendiri. Pengunkapan gagasan untuk menguatkan strategi muncul dari blok bangunan proposisi nilai sebagai titik permulaan. Selain itu, Kanvas Model Bisnis membuat strategi lebih focus dan terukur. Inovasi bisnis model diharap mampu meningkatkan keseluruhan kinerja UKM.
\end{abstract}

Kata kunci: UKM, model bisnis, inovasi model bisnis, industri kreatif, proposisi nilai 


\section{INTRODUCTION}

Creative economy is how people make money from ideas (Howkins, 2001). Data from Kementerian Pariwisata dan Ekonomi Kreatif RI (2014) pointed out that creative economy has absorbed more than 10\% labor, has contributed 7\% of Gross Domestic Product and 6\% of total export. In 2013, it was recorded 5.4 million enterprises engaged in the creative industries are mainly small and medium enterprises (SMEs). In order to achieve the prosperity and welfare as developed countries, it takes a high economic growth in the next five years. In 2019, the per capita income is expected to reach IDR 72,4 million (US \$ 6,037), an increase of $160 \%$ of income per capita in 2015, which estimated IDR 45,2 million (US \$ 3,766). To achieve this target, the Indonesian economy is expected to grow over 6\% per year (Kementerian Pariwisata dan Ekonomi Kreatif RI, 2014).

This paper is based on case study of several SMEs in Eastern Bandung (Babakan Penghulu Village). The four selected SMEs are expected to be the driver of local economyand estimated to be major icons of Babakan Penghulu Village. Their products are kids' Moslem apparel, bed sheets, pouches and bags as well as garment convection services. According to Law No. 20: 2008 on Micro, Small and Medium Enterprises (SMEs):

"Productive efforts belong to individual persons and entities or which meet the criteria for micro-enterprises, has a net worth of IDR 50,000,000,- (fifty million rupiah) not including land and buildings; or have annual sales of IDR 300.000.000,-(three hundred million rupiah)."

Based on the law above, these firms are included in Micro, Small and Medium Enterprises (SMEs) because of turnover per month up to IDR 30,000,000, - (thirty million rupiah).

However, SMEs lack both managerial and technical skills for their effectiveness (Rahman and Ramos 2010 in Hossain, 2015). Some common problems in SMEs are marketing, production and finance. The study was conducted through a fairly intensive mentoring. One mentoring is in marketing field such as branding, logo and packaging design. In fact, some SMEs have not had their own brand in sales. Some SMEs want a logo design improvements. Another important aspect is production. Production is still done manually and lack of manpower. During this time, the number of weekly production, inventory taking, and total sales were never recorded by SMEs. These become problems because SMEs cannot calculate a total capacity of production and the balance between sales schemes and production. Another major problem is that SMEs often faced financial problems both venture capital and financial bookkeeping.

Therefore, the problem formulation is how SMEs can overcome their lack of managerial and technical skills by Business Model Innovation? This study is aimed to evaluate the business strategy implementation and recommend business model innovations for SMEs especially in fashion and garment industry. Business model describes how a company does business (Osterwalder et al, in Carvalho and Jonker, 2015). Previous study found that most business have a diversity of activities in the business - a diversity of business models. These differences can often not be described rigorously by one core business model (Lindgren, 2013).

There are four important dimensions for SMEs which are interconnected: business plan, strategic planning business models, and entrepreneurship. An expanded business plan contains a strategic plan which consequently leads to a business model. These can be reflected the outcome of an entrepreneurial process (Carvalho and Jonker, 2015). An innovative business model can either create a new market or allow a company to create and exploit new opportunities in existing markets. Business model innovation can occur in a number of ways (Amit and Zott, 2012): (1) by adding novel activities, for example, through forward or backward integration; we refer to this form of business model innovation as new activity system "content." (2) By linking activities in novel ways; we refer to this 
form of business model innovation as new activity system "structure." (3) By changing one or more parties that perform any of the activities; we refer to this form of business model innovation as new activity system "governance."

\section{METHOD}

This study contained several stages in conducting research. Derived from the urgency of business model, this study was aimed to develop a Business Model Innovation for SMEs in Bandung especially in fashion and garment industry. The study was conducted in October to November 2014 by mentoring four selected SMEs in Babakan Penghulu Village-Cinambo Sub-District, Eastern Bandung.As stated above, businesses issues explained about creative industries and its competitive advantage to formulate value-creating strategies. Therefore, it started by analyzing general environment, including external environment and internal organization as an input. The tools used to analyze them including PEST analysis, Porter's Five Forces, Resource Based View and Value Chain Analysis. Finally, Business Model Canvas analysis was used as a tool and described more detail for SMEs' new innovative strategies.

As research methods, problem identification was the first step to obtain research objectives. Then literature review was conducted by collecting theory and information related with the research from various sources such as text books, journals, reports and previous study as secondary data. This study used qualitative approach based on field observation, mentoring four SMEs as a case study and Focus Group Discussion with the owners of SMEs. Qualitative approach presented the data analysis that helped mapping the existing business model of SMEs. Finally, the business model innovation was developed as recommendation which involve strategy implementation plan to improve performances of SMEs.

\section{RESULTS AND DISCUSSION}

\section{PEST Analysis}

Political, economic, social, and technological (PEST) factors that are included in macro environment factors are used to identify trends in external environment, which is challenging and complex. The firms have to adapt to the changes of its environment by changing their cultures, strategies, structures, and systems in order to be competitive. Political factor deals with the effects of government policy, includes government stability, taxation policy, and government regulation (Henry, 2011). Government support for SMEs aimed to encourage the growth and competitiveness in industry. The SME programs are directed to increase the income and welfare of the stake holders. In this case, Government is very powerful in determining regulations such as regulation of micro credit, labor, licensing, and product certification for SMEs.

Economy. Data 2013 showed that in Babakan Penghulu Village, there were 1,931 male residents and 2,672 female residents. The majority of population is in the productive age range. Babakan Penghulu Village has the very high potential work force. The majority of the residents' livelihood as laborers and factory workers. Based on educationlevel, the majority residents are only elementary or secondary school level. Babakan Penghulu Village has approximately $30 \%$ of poor households. Poverty is due to the lack of jobs, odd jobs (freelance workers), as well as the low level of education level. Poverty is also worsened by the number of uninhabitable houses. Babakan Penghulu 
Village has a lot of SMEs range from handicraft (bags from recycled plastic packaging and wallets), sewing (bedspreads, nightgowns, women's clothing), snacks, laundry, and more.

Social. Babakan Penghulu Village is chosen as the village to be developed its potential resource considering as follow: (1) Residents face major problems related to land ownership. Many of them rent a house with a very high cost of rent, or to be forced to work on the homeowner with the minimal salary. This problem has not been resolved until now and give a significant impact in economic, educational, and health. (2) Babakan Penghulu Village is a new urban village that undergo expansion in 2007. Because of it, this village still struggles with various problems. (3) The village has not received assistance ofJoint Business Group (Kelompok Usaha Bersama/ KUB) from the province. Unlike Cisaranten Kidul Village which received KUBIDR 160 million for 80 people (IDR 2 million per person). (4) The residents seems to have community spirit and collective enthusiasm, so they fight together to improve their living standards. This is an important capital in relieving poverty. Therefore, the spirit of togetherness and synergy are very important in starting new things such as start a business or improve an existing business. Therefore, there will be many challenges and the temptation to give up. The spirit of togetherness and a sense of collective will help them through various challenges and obstacles. (5) There is an authoritative figure who is respected by the citizens in managingthe improvement of living standards, Siti Khadijah. It is important to keep the direction, vision, and sustainability of the community empowerment program. Residents have a figure who is trusted, competent, and dedicated.

Technology. Hitt, Ireland, and Hoskisson (2011) argued that technological changes affect many parts of societies, through new products, processes, and materials. Both large and small firms should continuously scan the external environment to identify potential substitutes for technologies and newly emerging technologies to increase competitive advantage (Tsai and Wang, 2008; Lavie, 2006). A technological change involves the practical implication of scientific in an industrial context. A good technical infrastructure (e.g. internet network, machinery) would lead to better sales and production, resulting in cost and time efficiency. Technological factors affecting SMEs such as the rapidly e-commerce growth and the use of social media. Moreover, in its business operations, it needs sophisticated machinery and adequate transportation system. SMEs should study this technological change to understand its competitive implications.

\section{Porter's Five Forces}

The model evaluates the five factors that determine industry competition, defined as Porter's Five Forces. Porter (1985) argued that the five forces characterize industry structure and determine all firms' profitability in the entire industry. Thus, it reveals the important differences among industries. Moreover, it helps companies find a unique position and how industries evolve. Porter's five forces framework can help organizations to ascertain the attractiveness or profit potential of their industry by analyzing the relative impact of each of the five forces on their industry structure (Henry, 2011).

The threat of entry will depend on the existence of barriers to entry and reaction of existing competitor (Henry, 2011). The threat of new entrants is low. Startups with large financial resources can enter the industry. The low brand awareness and low customer loyalty represent low barriers to entry. Buyers, according to Henry (2011), can affect an industry by forcing down prices, bargaining for higher quality or services, and playing competitors off against each other. The power of buyers has further increased. The switching cost is low. Suppliers, according to Henry (2011), can exert bargaining power over by raising prices or reducing the quality of purchased goods and services. The power of suppliers are low because there are numerous suppliers to garment industry with various alternatives for manufacturer. Moreover, the switching cost is low. 
A substitute performs the same or a similar function as an industry's product by a different means (Porter, 2008). There are many substitutes for garment that meet similar needs to fashion. Buyers have lots of choices and substitute among garment and fashion products easily and the switching cost to the substitute is low. Rivalry among existing competitors takes many familiar forms, including price discounting, new product introductions, advertising campaigns, and service improvements (Porter, 2008). Rivalry among existing competitors is high since many garments and fashion firms offer competitive tariff, after sales service. Rivalry has also intensified because fashion industry is now essentially a mature service.

\section{Resource Based View}

Refer to Hitt, et al. (2011), internal organization which involves resources, capabilities, and core competencies, are the foundation of competitive advantage that lead to strategic competitiveness. Resource proposes that a firm has competitive advantages when it creates a successful strategy based on firm resources that cannot be duplicated by a current or potential competitor (Gordon, Lee and Lucas, 2005). Table 1 shows common tangible and intangible resources of SMEs.

Table 1 Resource-Based View

\begin{tabular}{|c|c|c|}
\hline \multirow{5}{*}{ 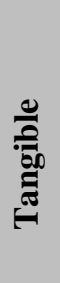 } & Types & Resources \\
\hline & Financial Resources & - $\quad$ Funding from personal \\
\hline & Organizational Resources & - There is no formal organizational structure \\
\hline & Physical Resources & - Appearance of physical facilities, such as building \& sewing machines, \\
\hline & Technological Resources & - Minimum internet network \\
\hline \multirow{3}{*}{ 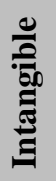 } & Human Resources & - $\quad$ Family and friends, trusted \\
\hline & Innovation Resources & - Still imitate \\
\hline & Reputational Resources & - There is no brand image \\
\hline
\end{tabular}

Capability refers to a corporation's ability to exploit its resources. A competency is a crossfunctional integration and coordination of capabilities (Wheelen and Hunger, 2010). There are four criteria of sustainable competitive advantage, as shown in Table 2.

Table 2 Four Criteria of Competitive Advantages

\begin{tabular}{lcl}
\hline \multicolumn{1}{c}{ Criteria } & & \multicolumn{1}{c}{ Competencies } \\
\hline Value Capabilities & Yes & $\begin{array}{l}\text { The resource or capability is valuable in delivering the firms' service to their } \\
\text { customer }\end{array}$ \\
Rare Capabilities & No & $\begin{array}{l}\text { There are many garment manufacturers and fashion designers in Bandung } \\
\text { The garment business is common and easy to be imitated. However, the } \\
\text { In-imitate capabilities }\end{array}$ \\
$\begin{array}{l}\text { SMEs has to put forward a satisfactory service to the customers. } \\
\text { Capabilities }\end{array}$ & Yes & $\begin{array}{l}\text { Basically, fashion products cannot be substituted. To survive in the market, } \\
\text { SMEs should differentiatetheir services so that business will continue to } \\
\text { survive among other competitors. }\end{array}$ \\
\hline
\end{tabular}




\section{Value Chain}

Value chain illustrates the product process from raw material to the end user/consumer. Create added value without substantial cost is an important notion of a value chain according to Hitt, et al. (2011). Porter (1985) divides the value chain into primary activities and support activities. The primary activity of the garment and fashion industry includes: (1) Inbound Logistics: activities include order entry, conception of products, fashion design, material handling, inventory control, and warehousing. (2) Operations: activities include the manufacturing, sewing, installing accessories such as buttons, mute/sequins, etc. (3) Outbound Logistics: activities include finished product handling, warehousing, order processing. (4) Marketing and Sales: activities include advertising and promoting, choosing the right distribution channels, supporting the salesperson, and distributing finished goods to retailers. (5) Service: activities including handling of complaints from buyers, after-sales service, repair bag/wallet, and so on.

The supporting activities consist of: (1) procurement/purchases: buy raw materials to make products including the purchase of assets such as machinery, sewing equipment, and buildings. (2) Development of technology: the process used to manufacture clothing. The development of this technology can be equipment, basic research and service procedures. (3) Human Resource Management: includes the activities of recruitment, training and payment of salaries to all employees. (4) Infrastructure: includes activities such as the legality, financial, general management, and the relationship with local government. Through their infrastructure, SMEs can effectively and consistently strive to identify opportunities from the outside (external opportunities), identify resources and capabilities (capabilities) and support the core competency.

However, creating value through the value chain activities sometimes require effective alliances with suppliers and build strong relationships with customers. If a company has a proximity to customersas well as suppliers, it can be said it is "social capital" of the company.At inbound stage, the activities are divided into two. When businesses accept orders from consumers in specific design, then the next step is to conceptualize the design desired by consumers. It is often found in the startup SMEs. Usually they receive a special order with a customized design from buyers. But over time, the SMEs have to start to offer their output design and make them as "trend maker". Of their ideas, finally they conceived product with a unique design that has its own characteristics.The next stage is production, handling of raw materials and finished products to be made by quality supervisorybefore distribute the products to the market. This stage is followed by outbound logistics consisting of packaging and labeling activities. Unique packaging both form and material could be the added value to the product.

After packing, the next process is marketing and sales. Goods distribute to end buyer, or other distribution channels. Currently, the online channel is emerging and strongly supports the development of creative economy, especially in the fashion sub-sector. With the promotion via twitter, Facebook, Blackberry Messenger profiles, Instagram and so on, lot of SMEs sell their products through these online channels. Other distribution channels is to open own shop or store products in other outlets. And last but not less important is service. After-sales services such as repair and other warranty can add value in a business process.

The simplest business model is to provide a good or service that can be sold so that revenues exceed costs and expense (Wheelen and Hunger, 2010). A business model describes the rationale of how an organization creates, delivers, and captures value (Osterwalder and Pigneur, 2010). There are many approaches to business model concept. This paper adopt business model from Osterwalder and Pigneur (2010) to evaluate the business model of SMEs. This tool provides a comprehensive yet simple map to plan, evaluate and manage its business model and helps to obtain effective alternative 
ways in doing business. There are nine building blocks of existing business model of SMEs as case study.

Firstly, in customer segments: this building block defines the different groups of people or organizations an enterprise aims to reach and serve (Osterwalder and Pigneur, 2010). For Lina Moslem Wear as fashion business, it has segmented customers while other garment services have mass market at low economy segment. Both segments have similar but varying needs and problems. This has implications for the other building blocks of business model, such as the Value Proposition, Customer Relationships, Distribution Channels, and Revenue streams.

The second building block is value proposition. This building block, according to Osterwalder and Pigneur (2010), describes the bundle of products and services that create value for a specific Customer Segment that may be quantitative (e.g. price, speed of service) or qualitative (e.g. design, customer experience). For middle-low economy buyers, value propositions such as inexpensive and fast service are important. Offering similar value at a lower price is a common way to satisfy the needs of price-sensitive Customer Segments (Osterwalder and Pigneur, 2010). Moreover, tailoring (customized) products to the specific needs of individual customers to create value.

The third building block is distribution channel. Refer to Osterwalder and Pigneur (2010), this building block describes how a company communicates with and reaches its Customer Segments to deliver a Value Proposition. For that, distribution channel often used by SME is word of mouth and their house as showroom or retail store. The fourth bulding block is customer relationship. According to Osterwalder and Pigneur (2010), this building block describes the types of relationships a company establishes with specific Customer Segments. Customer relationships may be driven by the following motivations: customer acquisition, customer retention, boosting sales (upselling). Customer relationship includes how to get new customers or retain existing customers. The nature of engagement with customers is an important factor in determining potential revenue of the business model. There are two kinds of relationship run by; long and short-term relationship. The Customer Relationships run by SMEs is co-creation that co-creating value with customers. SMEs engage customers to assist the design of new products.

The fifth building block is revenue stream. This building block represents the cash a company generates from each Customer Segment (costs must be subtracted from revenues to create earnings). Each Revenue Stream may have different pricing mechanisms, such as fixed list prices, bargaining, auctioning, market dependent, volume dependent, or yield management (Osterwalder and Pigneur, 2010). There are several ways that SMEsgenerates Revenue Streams, such as fixed list prices, bargaining. The revenue derives from selling products or charging sewing services.

The sixth building block is key resources. This building block describes the most important assets required to make a business model work refer to Osterwalder and Pigneur (2010). Key resources can be classified into tangible resources and intangible resources. The physical resources used for the key activities are sewing machines and workshop. The intangible resources include human capital and trust. The seventh building block is key activities. Refer to Osterwalder and Pigneur (2010), this building block describes the most important things a company must do to make its business model work. The key activities are producing products, marketing including selling and supply chain management.

The eighth building block is key partnerships. This building block describes the network of suppliers and partners that make the business model work. We can distinguish between four different types of partnerships: (1) Strategic alliances between non-competitors; (2) Coo-petition: strategic partnerships between competitors; (3) Joint ventures to develop new businesses; and (4) Buyersupplier relationships to assure reliable supplies (Osterwalder and Pigneur, 2010).Partner network for SMEs in garment and fashion industry consists of fabric suppliers 
Finally, the final building block is cost structures. Refer to Osterwalder and Pigneur (2010), the Cost Structure describes all costs incurred to operate a business model. The cost structure can be classified as operational liabilities, and non-operational cost.

The Business Model Canvas mapping is based on analysis and in-depth interview, as shown in figure 1.

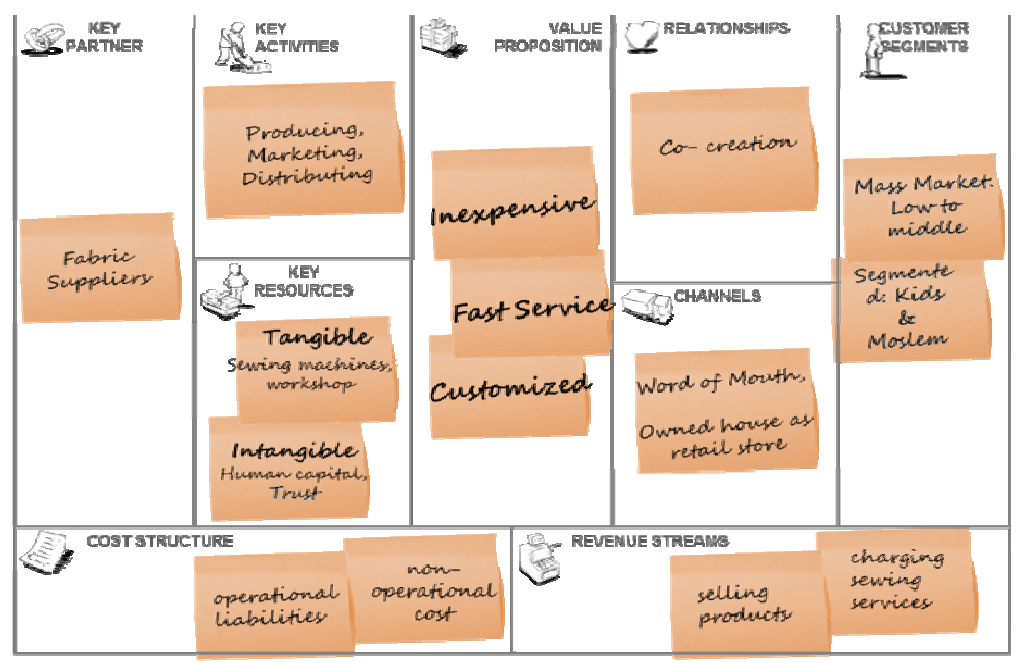

Figure1 Business Model Canvas

Business Model Innovation is principally about improving the nine blocks of business model. The new business model was mapped by considering alternative strategies formulated in business solutions above. Therefore, it requires SMEs to develop business model innovation as a business strategy solution. There are nine building blocks of business model innovation. First, new customer segments: SMEs especially in garment industry should focus on handling and serving the corporate segments with supplier-buyer relationships. For SME in kids' Moslem wear which serves a niche market, it could broad the target to family and offer couple outfit.

Second, new value propositions: brand can create value to customers. SMEs should build their own brand awareness. To consumers, brand provides important functions. In this case, consumers could realize benefits and advantages from purchasing the products. Moreover as long as they satisfy consuming the product, they are likely to repurchase. As problem identification, SMEs have not had their own brand in sales and want a logo design improvements. Author explains the importance of branding, logo design, and packaging in marketing. At the end, Author made some alternative proposed logo designs to SMEs.As garment and fashion industry, design can be a particularly important part of the Value Proposition (Osterwalder and Pigneur, 2010). Therefore, instead of offering service to make apparel, outfit, bedsheet and wallet, SMEs can offer and deliver their own design to the market at the low price.

Third, new distribution channel: the distribution channel should ease customers to reach. Since selling on internet (web sales) is very applicable in this garment and fashion industry, so that SMEs could communicate its value propositions and inform their service through its official websites and other social media -such as twitter, Facebook, Blackberry Messenger profiles, Instagram and so on, with the integrated marketing communication approach. Moreover, to introduce their products, boost the sales and build brand awareness, SMEs can join many events and exhibitions. Fourth, new customer relationship: many ways could be undertaken by SMEs to maintain the loyalty of their 
customers. The "Customer Priority" service - as in the commercial banks - could be addressed to corporate clients with the large volume and transactions for garment service. After that, integrated marketing communication approach might encourage SMEs to build personal online profiles. These automated services could encourage a personal relationship. Increasingly, SMEscan use communities to become more involved with customersand to facilitate connections between community members (Osterwalder and Pigneur, 2010). The communities, in this case, are such as recitation, labour union, and alma mater.

Fifth, new revenue stream: offering design and sewing service directly to existing customers generates revenue. The revenue comes from sales with fixed pricing by defining prices based on static variables such as price list and volume dependent. Sixth, new key resources: to meet the customer needs, resources must be added. Since the intangible resources include brand and design, thus SMEs should build brand image as well as invent and innovate year by year. SMEs could innovate and create the new products or new design as the most important assets. The physical tangible resources will be machinery and employees/freelance worker. Human resources i.e. experienced and skilled workers are crucial in creative industries.

Seventh, new key activities: with the new Value Propositions, automatically its key activities are also increased. Key activities are the tasks performed in order to develop the entire value proposition. In order to deliver its new value proposition i.e. design, the most important thing SMEs must do are hiring designers and launching a series of new products offers under the signature of their own brands.SMEs could adopt vertical growth strategy i.e. forward integration by opening new outlets or booths in events or exhibitions to reach new customers.

Eighth, new key partnerships: The key partnership form is buyer-supplier relationships to assure reliable supplies. Optimization and economy of scale partnerships are usually formed to reduce costs (Osterwalder and Pigneur, 2010). New partnership with Local Government and associations such as Indonesian Young Entrepreneurs Associationor another local trade community are crucial. SMEs create alliances to reduce risk in a competitive industry regarded as uncertainty. Ninth, new cost structures: Low Cost Structures are more important to SMEs' business models. SMEs could adopt cost-driven business models focus on minimizing costs wherever possible. This approach purposes at creating and keeping the leanest possible Cost Structure, using low price Value Propositions and extensive outsourcing.

The Business Model Innovation as recommended strategy is mapped in Figure 2 below.

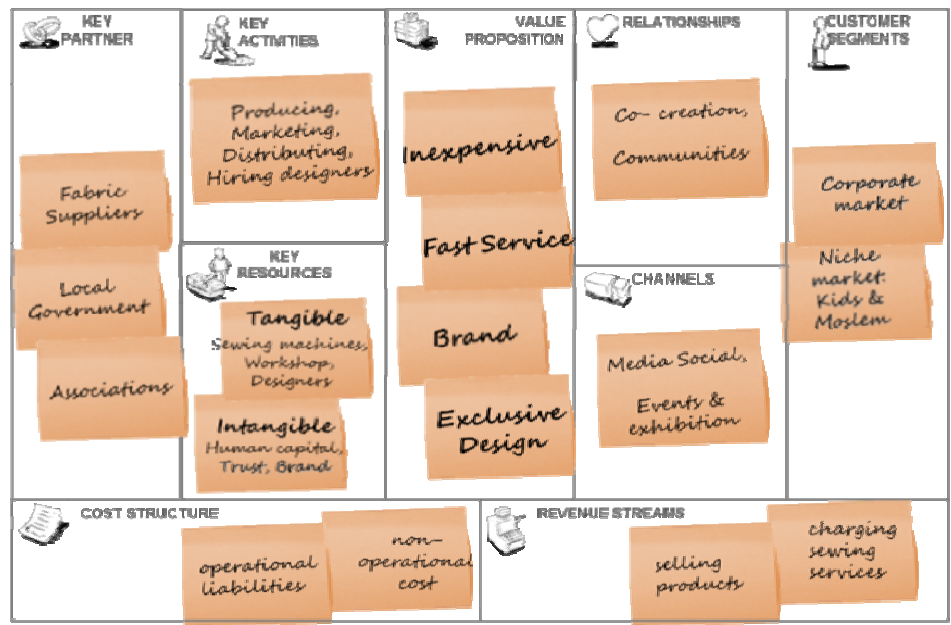

Figure 2 Business Model Innovation 


\section{CONCLUSION}

The creative industries play a significant role in the social and economic development especially in developing countries. Realizing the urgency of business model innovation help SMEs sustain and be competitive. From discussion above, it can be seen that SMEs need formulating a new value proposition to their customers i.e. brand and design to innovate the business model. SMEs should clarify their business model by understanding and implementing its strengths in creative industry i.e. garment and fashionsub-sector. Considering its business model, this study uses Business Model Canvas tool introduced by Osterwalder and Pigneur (2010), because of its comprehensive yet simple map. Ideation to strengthen strategies derives from areas identified through the value proposition building block as a starting point. Moreover, Business Model Canvas makes strategy more focused and measurable.

For SMEs, the key point of the business model innovation is to gain competitive advantage in industry. As stated above, an innovative business model can either create a new market or allow a company to create and exploit new opportunities in existing markets. To formulate strategies, business models evaluation is conducted by assessing existing business model which is expected to develop the foundation for improvements and initiate a business model innovation. This study also limited the scope of business only to garment and fashion industry. So that for future research, study on SMEs in several creative industry sub-sectors in Bandung is interesting to be conducted.

\section{REFERENCES}

Amit, R., Zott, C. (2012). Creating Value through Business Model Innovation. [Online] MIT Sloan Management Review, 53(3). Accessed 2 October 2013 from http://search.proquest.com/.

Carvalho, J. M. S, Jonker, J. (2015). Creating a Balanced Value Proposition: Exploring the Advanced Business Creation Model. Journal of Applied Management and Entrepreneurship 20(2), 4964. Accessed 17 November 2013 from http://search.proquest.com/.

Gordon, J.R.M., Lee P.M. \& Lucas H.C.Jr. (2005). A Resource-Based View of Competitive Advantage at the Port of Singapore. Journal of Strategic Information Systems, 14, 69-86.

Henry, A.E. (2011). Understanding Strategic Management (2nd ed). Oxford: Oxford University Press.

Hitt, M. A., Ireland, R.D., \& Hoskisson, R.E. (2011). The Management of Strategy: Concepts \& Cases (9th ed). South-Western Cengage Learning.

Hossain, M. (2015). A review of literature on open innovation in small and medium-sized enterprises. Journal of Global Entrepreneurship Research 5(1), 1-12. Accessed 16 November 2013 from http://search.proquest.com/.

Howkins, J. (2001). The Creative Economy: How People Make Money from Ideas. The Penguin Press.

Kementerian Pariwisata dan Ekonomi Kreatif RI. (2014). Ekonomi Kreatif: Kekuatan Baru Indonesia Menuju 2025. Jakarta: Kementerian Pariwisata dan Ekonomi Kreatif RI.

Lavie, D. (2006). Capability reconfiguration: An analysis of incumbent responses to technological change, Academy of Management Review, 31, 153-174 
Lindgren, P. (2013). Business Model Innovation Leadership: How Do SME's Strategically Lead Business Model Innovation? International Journal of Business and Management, 7(14), 5366. Accessed 16 November 2013 from http://search.proquest.com/.

Osterwalder, A., Pigneur, Y., \& Tucci, C.L. (2005). Clarifying business models: origins, present, and future of the concept. Communications of the Association for Information Systems, 16 (1), $1-38$

Osterwalder, A. \& Pigneur, Y. (2010). Business Model Generation. New Jersey: John Wiley \& Sons, Inc.

Porter, M.E. (1985). Competitive Advantage -Creating and Sustaining Superior Performance. New York: Free Press.

Porter, M.E. (2008). The Five Competitive Forces That Shape Strategy. [Online] Harvard Business Review January 2008. Accessed 9 October 2013 from http://hbr.org/2008/01/the-fivecompetitive-forces-that-shape-strategy/

Tsai, K.H., Wang, J.C. (2008). External technology acquisition and firm performance: A longitudinal study, Journal of Business Venturing, 23, 91-112.

Wheelen, T.L., Hunger, J D. (2010). Strategic Management and Business Policy - Achieving Sustainability $\left(12^{\text {th }}\right.$ ed). New Jersey: Pearson. 